\title{
MONEY AND SOCIALITY IN SOUTH AFRICA'S INFORMAL ECONOMY
}

\author{
David Neves and Andries du Toit
}

\section{ECONOMIC INFORMALITY IN SOUTH AFRICA}

This article examines the social dimensions of money in South Africa's informal economy by considering the interplay of agency, culture and context. Focusing on survivalist self-employment and impoverished livelihoods, the article aligns itself with socio-culturalist analysis (cf. van Donge 1992) of economic action, in order to examine the imperatives and networks that underpin practices of generating, accumulating and managing wealth at the margins of the economy, within the post-apartheid distributional regime.

Since it was first named by Hart (1973) almost four decades ago, the informal sector has been a longstanding domain of interest across an array of disciplines. Defying early predictions that it would be eclipsed or simply absorbed by the formal economy, the informal sector has continued to grow globally. As statebased economic governance has waned in the neo-liberal era, informality is increasingly evident in the global growth of outsourcing, casualization and industrial outworking (Chen 2007). Economic informality therefore appears to be less a residue of underdevelopment than a means by which a growing number of markets, economic activities and working lives are organized. In South Africa, those who work in the informal sector are marked by disadvantage. Almost 90 per cent of those in the sector are African (Devey et al. 2006), and relative to formal sector employees they are disproportionately female, and generally poor with very low average incomes (Rogerson 2007). Whereas in most developing societies the informal sector is the default option for workers unable to secure formal employment, in South Africa it is comparatively small and accounts for only a fifth of the workforce (Cichello et al. 2005). Despite widespread poverty and unemployment South Africa paradoxically has a lower proportion of informal employment than any comparable developing country (Foxcroft et al. 2002). The legacy of apartheid, which inhibited trade by Africans, sees the combination of a strong, formal economy in a developing country context, which serves to crowd out informal economic opportunities (Lund and Skinner 2003; Philip 2009). These gaps in informal sector activity are reflected in a paucity of research on those enterprises that do exist. The sector tends to be viewed in homogeneous and undifferentiated terms, misrecognized and misunderstood because of normative notions of economic 'rationality', or found wanting when measured with the

DAVID NEVES is a researcher at the Institute for Poverty, Land and Agrarian Studies (PLAAS), University of the Western Cape, South Africa. Email: dneves@uwc.ac.za

ANDRIES DU TOIT is Professor and Director of the Institute for Poverty, Land and Agrarian Studies (PLAAS), University of the Western Cape, South Africa. Email: adutoit@plaas.org.za 
yardstick of 'entrepreneurism' predicated on rational, self-interested, utilitymaximising individuals. Informal sector workers are prone to not keeping written business records, eliding enterprise and domestic accounts, and extracting seemingly unsustainably high levels of resources from their enterprises. They are motivated not by business plans but by various social and redistributional logics. Hence, in an influential comparative study within the business and management sciences literature, South Africa's impoverished (predominantly African female) informal sector workers are deemed to be innately lacking an 'entrepreneurial mindset' (Maas and Herrington 2006).

Although the informal sector is markedly larger elsewhere on the continent, it is viewed in similarly ambivalent terms. Attributions of cultural inadequacy are a common trope in accounts of African practices of economic informality. Narratives of the patrimonialism, clientelism, criminality and violence associated with accumulation (Bayart 1993; Fukuyama 1995; Bayart et al. 1999) routinely ascribe these to African cultural propensities and repertoires. Yet the enduring question remains, how precisely should the relationship between the social and economic realms be conceptualized?

Alternate modes of analysis, which avoid invoking the homo economicus of much conventional analysis, are less damning of sociality. They draw attention to the key role played by market actors (Granovetter 1985; 2005; Granovetter and Swedberg 2001), and to social networks and institutional dimensions (Beckert 2007). Institutions, governance and regulation serve to stabilize markets: expectations are seen as formed by the cultural, institutional and structural rootedness of market exchanges. These extra-economic factors include cultural mores, 'social networks and horizons of meaning within which market actors meet' (ibid.: 6-7). In this way, networks of trust and morality constituted within the socio-cultural environment enable economic production, distribution and consumption by stabilizing the social contingency inherent in exchange. They are present in all markets, but all the more significant in contexts where formal market institutions are absent or weak (ibid.).

This article draws on a socio-culturalist approach in order to re-examine some of the assumptions related to academic and popular usage of 'informality', particularly in the South African context. This approach argues that practices of accumulation are shaped by people's experiences and interpretations of social behaviour, rather than impersonal market logic (van Donge 1992; Beuving and Beuving 2004). Finally, economic informality seldom involves the absence of regulatory frameworks or institutions; instead, regulation takes place through popular institutions and networks, often beyond the ambit of the state (Meagher 2009).

\section{METHOD AND APPROACH}

In order to understand how informal self-employment is embedded in social networks, it is essential to capture dynamics of both household and enterprise: matters often separated or seen as the domain of divergent academic disciplines, theoretical perspectives and methodologies (du Toit and Neves 2007). Analysing the connections between them is important in order to capture their interaction: for example, the use of residential spaces for work, the use of unpaid kin, and the 
practice of extracting significant resources from enterprises for household use ('off-take').

The research project involved qualitative fieldwork in 2007 (ibid.), repeated (with the addition of several new cases) in 2009. Research was conducted in over 20 households, evenly divided between the African urban township of Khayelitsha in the Western Cape and a rural village in the rural Eastern Cape, in one of South Africa's spatially extended internal migratory routes. During multiple field visits, ethnographic interviews and observational research were undertaken into enterprises outside the regulatory net of taxation, occupational health and safety, and employment, zoning and trading regulations. Most were well-established, having run for a number of years. The National Small Business Act (1996 and amended 2004) designates a micro-enterprise in wholesale trade, catering and accommodation as one with fewer than five employees, a turnover below R200,000, and gross assets below R100,000 (RSA 2003); all the cases studied were well below this threshold. The cases were sampled to get a diversity of units by common enterprise types and enterprise operator demographics (such as age and gender). Research interactions with the enterprise operator focused on understanding self-employment activities and issues related to the enterprise, including history, structure, assets, employment, interaction with suppliers, access to credit and financial intermediation, and relationships with customers and with wider aspects of infrastructure and governance. Discussions with members of their corresponding households sought to understand-over time, and with visits in 2007 and later in 2009 - the history, composition and modes of livelihood involved, and to explore the nature of hidden transfers between the household and the enterprise.

Finally, in departure from the conventional anthropological practice of exegesis of a small number of case studies in their specific context, a relatively larger number of case study vignettes are presented and discussed in this article.

\section{THE POLITICAL AND RELATIONAL ECONOMY OF INFORMALITY}

Economic opportunity in contemporary South African society has been strongly patterned and shaped by the colonial and apartheid legacies of racialized underdevelopment. Three key legacies have been noted (Philip 2009): first, the centralized, vertically integrated monopoly structure of the core economy, with its highly skewed distribution of assets and capital; second, the racialized spatial legacy of township and homelands located far from economic opportunity; and third, the enduring legacy of inequality in the acquisition of skills and education. All of these contribute to a post-apartheid distributional regime marked by enduring poverty and some of the highest levels of income inequality in the world (Seekings and Nattrass 2006). These features are manifested differently in the two research settings. In the rural context of the Eastern Cape, the decline of remittances from migrant industrial labour, a century of state antipathy to smallholder agriculture, and the dissipation of the social arrangements which historically facilitated agriculture (Andrews and Fox 2004) intensify the process of de-agarianization evident across the continent (cf. Bryceson and Jamal 1997). Many households are both spatially 'stretched' between the urban Western and 
rural Eastern Cape and united by oscillatory migration (Spiegel 1996), yet prospects for urban employment are constrained by lack of skills in the workforce, steady post-Fordist decline in the resource extraction and manufacturing sectors, and the apartheid-era spatial legacy. De-industrialization in turn prevents people from reinvesting whatever urban earnings they have in rural livelihoods, and this exacerbates the decline of land-based livelihoods. South Africa is therefore a highly monetized context where formal employment opportunities have dissipated, and where millions have been adversely incorporated into the broader political economy (du Toit and Neves 2007). In this context, key to survival are state cash transfers, practices of social mutuality and reciprocity (or 'informal social protection', see Bracking and Sachikonye 2006) and endless repertoires of 'survivalist improvisation' (Davis 2006), including informal economic activity. The discussion that follows examines the latter.

\title{
The sociality of objectives
}

Daily survival rather than accumulation predominated in many informants' accounts of their motivations at these low levels of income. Yet despite this, as the two cases to follow indicate, there are often disparate and complex objectives to which informal economic activity is orientated. In some instances, as in the case study vignette presented below, impoverished people are able to develop longerterm financial goals, beyond immediate survival.

\begin{abstract}
Sibongile was a middle-aged woman who was running a spaza, take-away food and liquor store from her large sprawling township shack. She had run the business since her arrival in urban Khayelitsha outside Cape Town, when it was first settled. She learnt to trade with her husband, from whom she subsequently separated in the 1980s. However she continued to sell liquor on his behalf from her shop, despite the fact that he was resident elsewhere. Well-positioned relative to several local schools, the business made as much as R2,000 per week, and she had put several adult children through tertiary education and into the middle-class professions of teaching and nursing. A distant relative was working in the shop, but she maintained that he was not being 'paid'. The stipend she gave him weekly she called 'pocket money'. There were high levels of off-take: the household 'eats from the spaza shop' she explained. In 2007 she insisted the property was hers, but by 2009 , amidst the formalization of tenure associated with redevelopment (subsidized housing provision) in the township, she and her husband finally concluded a divorce and she lost her old shack and shop. She was building a house and shop on an adjacent plot, using some of the money she had been saving to enlarge the previous premises. In 2007 she was openly selling alcohol, but by 2009, in a context of heightened law enforcement, carried less stock and sold it more surreptitiously. Sibongile also described how she gave very little credit (after losing large amounts to bad debt), but extended some to the local teachers a week or so in advance of their payday, in anticipation of reliable repayment.
\end{abstract}

Although there was an uneven ability to quantify profitability, many informants, especially food retailers like Sibongile, extracted relatively high levels of resources ('off-take'), in the form of food, from their enterprises. Monetary gain was in these cases subordinated to this important off-take. The fungibility of money, and the ease with which it can be converted into various commodities, disguises the fact that although generating income and improving food security can overlap, they are subtly different objectives. In Sibongile's case, she managed 
to develop a long-term view of objectives, enabling her to educate her children into middle-class vocations. She aimed thereby to transcend the need of household members to work in the survivalist informal sector.

Objectives were sometimes even more complex and diffuse, as the next example, detailed below, suggests.

Magalama is a retired domestic worker, who sold bottles of Coca-Cola from her comfortable rural homestead. Morbidly obese and unable to walk far, she was unusual in our sample in that she effectively constituted a one-person household, although her urban-resident sons sent remittances. Throughout the course of the research Magalama hired a succession of caregivers and her accrued savings, state old-age grant, and the electrification of the village enabled her to acquire a refrigerator required to sell 'cooldrink'. This activity was perhaps most remarkable for the fact that it persisted over several years, despite its small scale. Magalama routinely sold a single case (12 bottles) a month, yielding a diminutive profit equivalent to no more than 5 per cent of her state pension. She continued to engage with it because it elicited a trickle of visitors and drew her into the social networks of a village where she was not well established. Similarly, she hired the labour necessary to engage in petty agricultural production (which on our calculation was merely breaking even) because, she said, 'it is our tradition'. However, it became apparent that offering the villagers casual employment (with payment in cash or in kind) was being used to channel their requests for material assistance, thereby deflecting redistributive claims and preserving her pension income.

In the above case study vignette, Magalama generated little income from vending - but this activity served to keep an otherwise mobility-impaired and isolated elderly woman, with weak links to the community, socially engaged. Having arrived in the village only on her retirement, Magalama was a relative outsider. Her marginality was compounded by her physical immobility, which imposed constraints on interacting with others and building social networks. Against this backdrop Magalama's soft drink vending assured her of the occasional visitor, cemented her place in social networks and integrated her into the relational life of the village. Although a poorly remunerated activity, it enabled her to enact appropriate forms of dignity, propriety and the sociality that Nyamnjoh (2002) terms 'conviviality'. This provided an opportunity for her potentially to mitigate some of the suspicion or even hostility she - as a socially atomized, elderly woman without locally resident male kin-might otherwise elicit within her village context. Financial gain was therefore not her primary consideration; instead, Magalama's activities were an instrumental part of her efforts to maintain her social respectability within the community.

Even amongst the small number of case study vignettes examined, informal economic activity was directed to a wide range of objectives: generating income, bolstering food security, facilitating social connectedness, slowing the draw-down of a finite portfolio of assets.

The neo-classical economic logic of maximizing profit and minimizing costs inadequately captures the potentially multiple objectives of economic informality; more variegated formulations better attuned to the socially embedded considerations which underpin informal economic activity are needed. To this end several writers (du Toit and Neves 2007; Petersen and Charman 2008; von Broembsen 2008) have suggested that informal economic activity be understood not only as productive and income-generating, but as a reproductive activity orientated to 
sustaining household survival. The divergent objectives to which economic informality is directed, the porous boundaries between the domestic and enterprise realms, the persistence of household-level production and subsistence activities: all suggest that despite the predominance of the formal market in South Africa, patterns of micro-accumulation at the margins are incompletely capitalist in character, and may even have continuities with earlier pre-capitalist modes. These patterns of accumulation also contradict commonplace, evolutionary assumptions about the growth of markets and linear progression of economic development (cf. Ferguson 1999; Humphrey 2002).

\section{Sociality and economic governance}

Informal economic activity and the conditions under which it occurs are inextricably bound up with regulation and governance. While much scholarship is concerned with state-based regulation, increasingly the importance of informal, non-state governance of informal economic activity has been emphasized (Roitman 2005; Meagher 2010). Although both varieties are considered here, it is within informal non-state governance that social networks play a particularly prominent role. Regimes of governance are contextually rooted and spatially patterned; in this inquiry they take on different forms at the urban and rural sites.

A significant difference in formal governance between the rural Eastern Cape and urban Cape Town is the institution of the hereditary chieftaincy. In South Africa's bifurcated regimes of governance and citizenship, urban residents are the 'citizens' of civic authority while the rural residents in the communal area of the former homelands are the partial 'subjects' of hereditary traditional authority (Mamdani 1996). Chiefs dispense (often uneven) rural governance and exercise much of their authority in relation to local land administration and the adjudication of disputes. Many of the self-employed in our rural fieldsite, such as taxi operators, derive their right to trade from communal recognition, and local residence in a particular locale. Rural taxi operator Nselo, described below, was one such person.

Nselo was a man in his fifties who ran a passenger taxi (based on a pick-up truck and known as a quqa) from his rural Eastern Cape village. The pick-up carried ten tightly squeezed passengers seated on wooden benches in its load bed under a fibreglass canopy, and operated on a route traversing twenty-odd kilometres of unpaved roads to the local town. In 2007 he owned a quqa, a second pick-up for carrying goods, and a third that had been wrecked by an errant driver. Nselo occupied a comfortable rural homestead, his parents had been members of the petty rural elite, and he had a relatively favourable and long history of formal-sector urban employment. It was during this period that he acquired a township house and a Sotho wife from the industrial heartland of Gauteng. Through this urban employment and the beneficence of local (schoolteacher) elite kin, Nselo gained the literacy, capital and driving skills to run his business. Although he owned an uncharacteristic range of financial products (including a small endowment), he lamented the low profitability of the enterprise and eagerly sought microfinance from the researchers. By 2009 he had disposed of two of the vehicles and continued to ply his trade with failing eyesight and increasingly unfavourable attention from the local traffic authorities. He continued to lament his low profitability and high maintenance costs. An absence of provisioning to replace his vehicle suggested the income it earned was merely a way of cushioning the inexorable draw-down of his formal sector savings. 
With his connections to the village elite, Nselo epitomized the local residence and association membership required to successfully operate a quqa. He explained that for a new entrant to engage in the same enterprise he would have to be a part of the village, by securing a homestead site via the local headman. Furthermore running a quqa requires membership of the local 'taxi van' association, with its attendant 'joining fee' and its prescribed fixed route between the village and town. Although the association is voluntary and lacks statutory underpinning, Nselo thought it inconceivable, if not provocative, that a non-member would attempt to run a quqa. Regimes of informal governance are potentially almost as variegated as the formal: unlike his passenger-carrying quqa, Nselo's goods-carrying pick-up truck neither travelled a fixed route nor offered a service limited to his own village. The two vehicles constituted different enterprises, were subject to different conditions and necessitated membership of two voluntary associations.

The variegated nature of authority and governance is further illustrated by the case study vignette below.

Cynthia, a hairdresser in her mid-thirties, and her sister ran two 'hair saloons' at the Khayelitsha taxi rank, operating from converted steel shipping containers which they purchased five years after arriving from Zimbabwe, having left that country as economic conditions deteriorated. Cynthia and her sister had formal hair dressing qualifications, which she thought distinguished them from many of their local competitors. Cynthia sent regular remittances to their family and their father was temporarily resident with her as he sought medical treatment in Cape Town. She closed the containers during a bout of xenophobic violence in 2008, and readily explained they would one day like to return to Zimbabwe. Cynthia was seeking to position herself as a wholesaler of a range of 'ethnic' (sic) haircare products. She paid a small weekly 'sweeping fee' to the local taxi association, which, she explained, deterred criminals.

In the urban townships forms of informal civic authority were also evident and took on particular local forms. Accounts of street committees were prominent in people's recollections of how they had originally been allocated trading sites. The role of street committees had been reanimated with the ongoing upgrading of the area. In addition, those working in close proximity to the taxi rank indicated that they were able to appeal to the offices of the local (minibus) taxi association if they had a dispute with a debtor or employee, suggesting that the governing powers of such associations extend beyond the immediate remit of their own business interests. Many informants, such as hairdresser Cynthia, reported that they paid the 'sweeping fee' to the local taxi association. It was clear that the local taxi association was widely regarded as a source of governance and a buttress against unsanctioned claims in the form of criminal victimization. In a context marked by high levels of informality the local taxi association thus represents an important vector of local governance. The rank, located on municipal land and nominally overseen by the municipality, is effectively controlled by the taxi association. The association's authority has a spatial dimension; it radiates outwards from their offices at the taxi rank, being robust at the centre but dissipating for enterprises situated further away. The township can be conceptualized as consisting of a number of overlapping, concentric rings of authority and governance.

These are situations of informal economic governance in which enforcement through violence or the threat of violence is central, and where the state is far from assured of a monopoly on such violence. An official government inquiry into the 
taxi industry in the Western Cape found the taxi associations operate "like a modern day mafia with the power to extort monies from operators, the ability to kill people who disagree with them and threaten their interests' (Western Cape Provincial Government 2005: 111). The inquiry report is replete with accounts of the use of covert iimbovane ('ants', or assassination squads) to murder rivals and the amassing of vast unaccounted-for 'war chests', secretly used to 'hire hit men, buy illegal firearms, employ the services of traditional healers, pay for legal fees, bail for those arrested, pay families of iimbovane and maintain the services of those involved in violence' (ibid.: 98; see also Dugard 2000). Informality and violence are frequently responses to regulatory retreat and the legacy of enduring economic disadvantage (Meagher 2009). In the context of the taxi industry, even the official inquiry readily identifies how a regulatory vacuum provides the conditions for violence (Western Cape Provincial Government 2005).

Informality, the social networks which shape it, and the often violent associations which police it, nonetheless intersect with practices of formal governance. Both the rural and urban fieldsites were subject to regimes of formal regulation associated with the South African state, including environmental health regulations (for food retail), land-use planning (zoning), and regulations controlling matters as diverse as liquor consumption and sale, and road traffic. This state-led regulation coexists uneasily with non-state forms of governance. It also has different manifestations and intensities of enforcement in different locales, with state and formal regulation relatively scanty in the rural area, but more present (albeit unevenly) in the urban locale. In the case of Nselo's rural taxi, the drivers of vehicles who carry passengers for gain are required to hold a Public Drivers Permit (PDP) in addition to their regular driver's licence. However while national traffic regulations permit the transportation of passengers in the load bed of a truck, they may not be carried in the load bed for gain, as fare-paying passengers. ${ }^{1}$ Yet in practice these formal regulations were accommodated to the reality of the ubiquitous quqa taxis. Traffic authorities routinely overlook the statutory prohibition against carrying passengers in open trucks for gain, yet enforce the requirement for the PDP. A local traffic enforcement authority readily conceded that pick-up truck taxis were unsafe but attributed parochial tolerance of them to the fact that local residents were 'poor' and could not afford a more suitable mode of transport. It was tacitly understood that the vehicles would travel only between the rural villages and local town, rather than the 'white' town outside the former homeland and about 100 kilometres away. To do the latter would incur, by way of punishment, an invocation of the overlooked rule and certain legal sanction. Regimes of governance are therefore contextual, variegated and spatialized in terms that are typically widely understood by both enforcers and enforcedagainst.

This nested and hybrid combination of formal and informal, in relation to the taxi and quqa regulation, disrupts any sense of a sharp binary between informal and formal, sanctioned and unsanctioned, from socially embedded to disembedded (Polanyi 1957). Instead it recalls Guyer's (2004) notion of patchwork 'formalisms'. Comparable syncretism is evident in accounts of the 'mixed

\footnotetext{
${ }^{1}$ Regulation 247 of the National Road Traffic Act merely specifies a minimum height of the sides of the goods area of a truck in which passengers are carried.
} 
embeddedness' of informal emigrant enterprises in the Netherlands (Kloosterman et al. 1999), which are constituted within the twin contexts of communal and social networks, on the one hand, and overarching relationships to the state and formal economy on the other. Informal economic activity in South Africa is likewise undertaken in the interstices of a powerful formal economy and a state that is far from 'hollowed out'.

\section{The sociality of trading}

The social demands of trading are illustrated in the story of Neliswa, a tailor in Khayelitsha.

Middle-aged widow Neliswa sewed traditional 'German print' for the traditional matrimonial market, and sold her wares from a stall at a taxi rank in Khayelitsha. Alongside her sewing she also engaged in Zionist-Pentecostal healing from her Khayelitsha shack for 'donations', and sold shoes in a more distant township. Neliswa started selling clothes from her home in the rural Eastern Cape after the death of her husband over two decades previously, using his formal workplace pension as capital. In the 1990s she came to Cape Town, lived with her sister and continued sourcing and selling clothes and footwear from distant Durban while schooling her children. It was at this time that she completed a sewing course and started making the traditional wear, which is not subject to the same Asian competition as other garments. By 2007 she also carried a large book containing the records of debts owed to her (about R4,000) for shoes sold in a distant Cape Town township. She favoured the distant site because it was easier to collect debt where she was unknown, as people 'don't come with stories'. Neliswa was relatively unusual in having a paid, non-kin employee working at this site while she sewed from her home. She attributed the lack of crime to the local taxi association, which deterred criminals and was also able to adjudicate local disputes.

The related activities of conducting trade and managing money can evoke significant innovations and acts of accommodation, while also revealing contradictions. Especially demanding is the need to manage socially redistributive claims and networks, keeping them at bay while nonetheless engaging with them. This variously required disembedding (Neliswa's selling shoes to strangers rather than neighbours), deflecting claims with alternative activities (in the earlier example of Magalama's agricultural labour), or mustering the authority and force to meet coercive redistributive claims. So powerful are such redistributive claims that fear of crime is cited as a reason for reluctance to engage in self-employment (Cichello 2005). On the other hand, the need to maintain a client base and the demands of sociality require that such social networks be sustained.

The task of trading in the informal sector entails the juggling not only of different social imperatives but also of enterprise considerations such as the setting of prices. In both fieldsites, prices, especially for standard mass-produced goods, were often uniform. There appeared to be a widespread reluctance to engage in price competition, and many informants stated that they refuse to consider competing on price. Petersen and Charman (2008) document how informal sector vendors scrupulously avoid discounting, but instead compete in terms of factors which are not (directly) price-related. Engaging in 'covert competitiveness', such vendors instead seek to secure favourable spatial locations or attractive supplier discounts, or build good relationships with customers. Indeed, traders such as Neliswa routinely engaged in hearty and good-natured 
banter with customers, which they understood to be part of their sales strategy and competitive advantage. When questioned on their competitive strategies, traders were frequently vague and coy to a degree that cannot merely be ascribed to proprietorial secrecy. They often attributed their success to luck.

That social opprobrium against price competition was a significant factor discouraging traders from practising it is illustrated by an example of its violation. Xenophobic violence against Somali township traders in 2008 was largely attributed to their superior retail prowess and the inroads they made into local spaza shop trade. Organized and experienced Somali traders routinely undercut local spaza shops, with a report commissioned by local government claiming that

the tensions that exist between foreign and local spaza shop owners are due to the fact that the spaza shop market is becoming increasingly competitive often resulting in local spaza shop owners not being able to compete effectively with foreign spaza shop owners in terms of price and changing customer preferences. (KLS/CCT 2009: 46)

Xenophobia is undoubtedly a complex phenomenon with multiple causes and long antecedents, but it is clear that by successfully engaging in overt price-based competition, the Somali traders violated prevailing retail practices and local repertoires for the creation and capture of value. These practices elicited extreme antipathy from existing traders. The force of the tacit prohibition against price competition cannot simply be understood as anti-competitive collusive behaviour. Instead, sociality is invoked to contain the moral disorder of money. It guards against the conflict, jealousy and social disruption associated with accumulation, in a resource-poor context, with deeply rooted (albeit highly contradictory) ideologies of social reciprocity and communalism.

\section{The sociality of money: debt and credit}

The demands of managing money, debt and credit are key tasks in the context of economic informality (Hart 1973; Roitman 2003). The informal sector in South Africa is tightly intertwined with formal sector value and commodity chains. With the single exception of traditional medicinal herbs, virtually all products retailed or manufactured in the informal sector derive directly from suppliers of products or raw materials in the formal economy (Skinner 2006). South Africa has long been subject to the forces of commodification and monetization, and the prospects for independent subsistence production have long since waned (Wolpe 1972). In the urban and rural fieldsites, these conditions also reflect the linkages of informal enterprises to the formal labour market in the form of wages, workplace pension, and provident or retrenchment packages. ${ }^{2}$ Informal enterprises were intertwined with formal sector cash inputs. The linkages between the formal and informal sector include not only the leveraging of resources derived from the formal sector into informal enterprises, but also an extensive interaction between formal and informal sector employment (Devey et al. 2006). In the case studies, the few cases that did not have such labour market linkages had enjoyed other distinctive strengths such as the early acquisition of particularly favourable

\footnotetext{
${ }^{2}$ Even comparatively generous (by developing country standards) social grants represented a variety of 'formal' income.
} 
trading sites. In general terms, however, successful, sustained trade required linkages to the formal sector.

Credit constraints have been identified as a hindrance to self-employment elsewhere in the literature (Cichello 2005), but the empirical findings suggest that this is a complex issue. While some informants readily described themselves as needing money or credit such as microfinance, others resisted this idea. For example, Sibongile was vocal in her criticism of what she felt were extortionate interest rates. Doubting her ability to repay microfinance, she turned it down. In anticipation of the expansion of her business in 2007 she had saved a considerable part of the requisite R30,000. By 2009 she had diverted this sum into the construction of a new spaza shop and house, after her ex-husband had reclaimed her previous premises following their divorce. Furthermore, with informants' expectations cued by popular and official discourses of microfinance, what might appear to be a credit constraint may reflect the harder realities of low profitability. Enquiries about the credit took place in a national and international context where microcredit was regularly touted as an appropriate policy response to the problems faced by the SMME (Small, Medium and Micro Enterprise) sector. It was therefore unclear how far informants' desire for microfinance was being reflexively shaped by its discursive popularity and relative availability. Hence Nselo's claim that he needed credit to fix a wrecked vehicle in 2007 was undercut by the fact that he held an uncharacteristically diverse range of formal financial products, and yet, despite having access to such products, subsequently sold off the unproductive vehicle rather than mending it.

Apart from difficulties in securing credit, a key factor in running an informal sector enterprise is the task of dealing with the pervasive demands for credit, in a resource-poor setting where impoverished Africans typically rely on a vast and complex range of financial instruments. Detailed research amongst this group, based on the keeping of financial diaries, documented an average of eleven credit 'instruments', most of which were informal (Collins 2005; Collins et al. 2009). Those in the informal sector responded to these demands in ways as complex as those deployed in the management of redistributive claims described earlier. Some, such as Sibongile, strenuously resisted granting credit, while others, like Neliswa, acquiesced, but maintained written records, and strategically sold her wares in areas where she was not resident, arguing that people would be more inclined to pay their debt if she was socially distant. Radebe, whose narrative follows, engaged in elaborate procedures for vetting potential debtors by getting his employees to record debtors' cell phone numbers, establish their employment status and visit their residential addresses. In these cases, the management of customer demand for credit entailed one of two broad strategies. The first involved deflecting and resisting demands, including using strategies to avoid claims of social entitlement with their attendant risk of non-payment. The second involved building the kinds of sociality and 'weak links' (Granovetter 1985), networks, social surveillance and pressure required to successfully collect debt.

Similar efforts to manage social claims loomed large in accounts of saving. For many the key imperative with saving is the need to organize cash flows and smooth consumption: an objective which often predominates over tactics such as building assets or gaining favourable interest rates (Collins et al. 2009). The literature is replete with practices such as borrowing from microfinance projects in 
order to save informally, or charging an increment for the daily collection of small deposits instead of paying the interest of formal banks (ibid.). In our fieldsites, savings practices were tightly interwoven with social networks and practices, especially through the widespread use of informal Rotating Savings and Credit Associations (ROSCAs) or financial mutuals: amacalelo in isiXhosa (see Bähre 2007). Informants with more to save often hedged their risk by belonging to more than one such assocation. In these cases the sociality and risk mitigation gains obtained by participation in multiple ROSCAs trumped the increased effort and transaction costs involved. Research shows how impoverished Africans' access to new income streams associated with the receipt of a social grant results in a slightly higher uptake in formal debt, but these recipients generally continue to maintain a portfolio of formal and informal financial instruments (Neves et al. 2009).

A final point underscoring the social dimensions of saving and accruing value is that many forms of wealth, such as household labour capacity or communally owned land, are not readily commensurate with or convertible to money. Social logics dictate that cattle may be converted into an abstracted monetary 'sphere of exchange' only reluctantly (Ferguson 1992), or sold by entrepreneurs keen to acquire trading stores only with great circumspection (Bank 1997). Owners of such stores of wealth walk a social tightrope between engaging with new opportunities of accumulation and remaining committed to a communalistic range of social meanings and obligations. In this way they seek to ensure that short-term fiscal gains will not come at the cost of disrupting the moral and social underpinnings of longer-term 'transactional orders' (Bloch and Parry 1999).

\section{Formalization and sociality}

This final section explores the place of sociality against the backdrop of ongoing processes of economic formalization. An influential argument is that those in the informal sector are constrained through having to transact within their social networks and to rely on relational systems of interpersonal guarantee. Accordingly contemporary policy injunctions argue for access to formal services, entitlements and protections (de Soto 2000). Formality promises access to systems of legal redress, secure tenure, protection from hazards, and access to infrastructure, opportunities and markets. However, formality can constitute a threat to social networks and patterns of sociality, rendering its benefits equivocal. The potentially deleterious consequences of formality were evident in the case study vignettes of mechanic Zikhode and tinsmith Radebe.

Gaunt and with the scarred face of a fighter, forty-five-year-old Zikhode was one of a loosely affiliated group of mechanics who repaired and serviced vehicles (primarily taxi minibuses) alongside a Khayelitsha taxi rank. Although they shared some tools, they effectively worked as individual contractors and were hired by the taxi drivers or owners. Earnings were highly variable, and they extended little credit. Zikhode, like the others, had no form of collective savings or insurance. He was entirely self-taught. Although resident with his parents in 2007, Zikhode made a limited and clearly delineated contribution to the household economy, but he refused to assume responsibility for his younger siblings. With low living costs and uncomplicated domestic arrangements, he appeared to be making enough money to engage in discretionary expenditure on daily hot lunches and alcohol. 
By 2009 he was imprisoned and awaiting trial on hijacking/theft charges (accounts were contradictory), but insisted on his innocence and ascribed his arrest to a case of mistaken identity. Released from prison in late 2009 (possibly on bail, or with the dismissal of the case: accounts were contradictory), regular meals and enforced abstinence from alcohol saw a radiant-looking Zikhode return to work at the taxi rank. His enthusiasm was marred, however, by his sense that 'jealous' (envious) neighbours had had some hand in his recent incarceration, and by his concern at the advent of a new generation of larger, more technologically complex and dealershipserviced taxis. The government's taxi recapitalization programme had introduced these new Japanese-sourced minibus taxis, and he was precluded from repairing them. Not only is accredited maintenance a condition of the manufacturer's warranty and service plan, but repairing the technologically advanced vehicles requires complex electronic diagnostic equipment and specialist skills. He possessed neither, and worried about this threat to his livelihood.

In this example the exclusionary potential of formality inheres in a combination of both regulatory change and technological 'lock out'. Zikhode viewed himself as a skilled mechanic and wished to obtain training, primarily for the certification it would confer. He reasoned, perhaps with justification, that this formal endorsement of his skills would enable him to secure a formal sector job, and thereby exit the informal sector. The promise of training was not that it would enable Zikhode progressively to formalize, upscale or grow his informal economic activity, but rather that he would be able to abandon this sector and social network altogether. Zikhode's was a common aspiration in a context such as contemporary South Africa where the formal sector predominates, and informality represents a poor substitute. The case of tinsmith Radebe similarly reflects the ambivalent consequences of formality.

Radebe lived by himself in Khayelitsha and supported a wife and family resident in the rural Eastern Cape through the pension he received and his work as a tinsmith. Manually, using hand tools, he fabricated items from tinplate, which were sold via employees at several sites. Although basic and utilitarian in design, his wares were extremely well-made and included specialized products such as large goat-sized cooking pots adapted from 44-gallon drums, and a range of utensils and strainers used for brewing traditional sorghum beer. Despite his relatively lucrative and skilled niche enterprise, which allowed him routinely to remit to his family in the Eastern Cape his entire unspent state pension, Radebe faced a number of constraints. The first was the loss of his workshop space. During the redevelopment of the township he was randomly selected to be relocated, as part of 'de-densification' of the shacks, and his newly allocated concrete block house was not only distant from viable vending points but surrounded by similarly relocated strangers. These new neighbours were far less tolerant of the noisy hammering from his home workshop, which they complained was an affront to their respectable new suburban homes. He solved this problem by building a rudimentary shelter alongside a busy arterial route from which to work and vend, but the structure was soon demolished by the municipal authority. By 2009 he had built an even more rudimentary structure (of scrap wood, plastic sheeting and cardboard) elsewhere. The second constraint was Radebe's difficulty in sourcing the printed or painted metal (tin, zinc and aluminum) sheeting he required. In the past, intermediaries associated with a local development project had helped him source this material. However by 2007 the scrap tinplate he coveted was increasingly scarce, amidst the efficiencies of industrial automation and formal tendering out of scrap metal collection by local can-making companies. The difficulty of engaging with these sources was exacerbated by Radebe's 
lack of English or Afrikaans language skills, literacy and social confidence. A third constraint was his relationships with the three elderly women he employed to sell his wares, which seemed fraught with mistrust. He alleged on several occasions that they were swindling him.

Radebe's case demonstrates the workings and results of formality. Prevailing state models for the provision of housing infrastructure privilege formalization, and for many years the informal settlement areas of Khayelitsha have been subject to redevelopment efforts. The upgrading of informal shacks through their replacement by serviced low-cost housing entails the building of infrastructure and allocation of title deeds. Although keenly desired by residents, and doubtlessly an improvement in their general living conditions, this formalization has disadvantages. Despite the intuitive appeal of formalizing property rights, some argue that it may not increase tenure security (particularly of vulnerable groups); that it often does not provide an asset that can be used to access credit; and that formal systems frequently ignore or swiftly become out of step with extra-legal realities (Cousins et al. 2005). Furthermore, Radebe's case illustrates the manner in which the upgrading of informal settlement disrupted longestablished social networks and informal livelihood opportunities. Echoing some of Zikhode's experience, Radebe's artisanal work space and vending sites became compromised and lost through processes of formalization.

The case of Radebe also demonstrates the process of exclusion from a previous supply chain of material by technological change. His former suppliers automated their processes, thereby generating less scrap metal, and formalized their waste recovery by contracting an industrial recycler. This exclusion was also driven by concerns about branding and intellectual property, as the scrap tinplate from the canning industry was printed with the brand names which the manufacturers now scrupulously controlled. (A canning company employee explained that they did not want to sully their 'brand equity' by having it 'turned into township stuff'). Radebe's exclusion was therefore driven by the fourfold shifts in the spatial, technological, industrial and intellectual property regimes around him. Not only is formality often piecemeal (Guyer 2004), and intertwined with informality in complex and hybrid ways, but it clearly occurs across a multitude of possible domains.

The consequences of formality for those in the informal sector are not uniformly adverse, however. They are dependent on the specificity of the structural and social positions people occupy, and whether they are able to position themselves to benefit from change. Some find ways to profit in the 'creative destruction' associated with new regimes of formality and market relations.

\section{CONCLUSION}

This article has analysed small-scale survivalist economic activity at the margins of the South African economy, and examined the often complex social dynamics and imperatives that underpin it. The case study material presented suggests how much social skill and adeptness is required to eke out a viable livelihood from the small arenas of economic opportunity contained in the informal sector, in 
addition to technical skills and key positional factors. To those in the informal sector, social considerations shape and inform the diverse objectives of their activities. Economic activity is neither understood, nor is its viability judged, simply in relation to the maximization of profit. Instead enterprises are viewed in terms of the extent to which they balance up the multiple objectives of securing resource flows (fiscal and otherwise), making investments (material and social) and mitigating risk. These diverse enterprise objectives, the varied strategies of small-scale accumulation they embody, and the manifold social identities with which they are entangled, reveal much about patterns of economic development at the margins. Varied, variegated and non-linear, these trajectories of economic development serve to challenge the assumption that the economy becomes progressively disconnected from society as it becomes more formal.

The article also highlights the centrality, to those in the informal sector, of managing socially redistributive claims and practices within their broader social networks. The demands of managing social claims were evident in relation to a number of domains, including negotiating those practices of economic governance - both formal (state-led) and informal - which provide the conditions of possibility for economic activities. Finally, the article examines the encroaching processes of formalization, describing their often ambivalent effects on those on the economic margins. Those in the informal sector typically seek to negotiate the consequences of these, and simultaneously carefully position themselves to harness the benefits of formalization, while evading its considerable constraints.

\section{ACKNOWLEDGEMENTS}

The support of Deborah James is gratefully acknowledged. This work was partly funded by a grant from the Economic and Social Research Council of the UK (award RES-062-231290), which we gratefully acknowledge. Opinions expressed are our own.

\section{REFERENCES}

Andrews, M. and R. C. Fox (2004) 'Undercultivation and intensification in the Transkei: a case study of historical changes in the use of arable land in Nompa, Shixini', Development Southern Africa 21 (4): 687-706.

Bähre, E. (2007) Money and Violence: financial self-help groups in a South African township. Leiden, Brill.

Bank, L. (1997) 'Of livestock and deadstock: entrepreneurship and tradition on the South African highveld' in D. F. Bryceson and V. Jamal (eds), Farewell to Farms: de-agrarianisation and employment in Africa. Aldershot: Ashgate.

Bayart, J.-F. (1993) The State in Africa: the politics of the belly. London: Longman.

Bayart, J.-F., S. Ellis and B. Hibou (eds) (1999) The Criminalisation of the State in Africa. Bloomington IN: Indiana University Press.

Beckert, J. (2007) 'The social order of markets', Discussion Paper 07/15, Max Planck Institute for the Study of Societies, Cologne.

Beuving, J. J. (2004) 'Cotonou's Klondike: African traders and second-hand car markets in Benin', Journal of Modern African Studies 42 (4): 511-37. 
Bloch, M. and J. Parry (1989) 'Introduction: money and the morality of exchange' in J. Parry and M. Bloch (eds), Money and the Morality of Exchange. Cambridge: Cambridge University Press.

Bracking, S. and L. Sachikonye (2006) 'Remittances, poverty reduction and the informalization of household wellbeing in Zimbabwe', Global Poverty Research Group Working Paper Series, GPRG-WPS-045, < http://www.gprg. org/pubs/workingpapers/default.htm >, accessed 11 November 2007.

Bryceson, D. F. and V. Jamal (eds) (1997) Farewell to Farms: de-agrarianisation and employment in Africa. Aldershot: Ashgate.

Chen, A. M. (2007) 'Rethinking the informal economy: linkages with the formal economy and the formal regulatory environment', DESA Working Paper No. 46, United Nations Department of Economic and Social Affairs, New York.

Cichello, P. (2005) 'Hindrances to self-employment: evidence from the 2000 Khayelitsha/Mitchell's Plain Survey', Working Paper 101, Centre for Social Science Research, University of Cape Town.

Cichello, P., G. S. Fields and M. Leibbrandt (2005) 'Earnings and employment dynamics for Africans in post-apartheid South Africa: a panel study of KwaZulu-Natal', Journal of African Economies 14 (2): 143-90.

Collins, D. (2005) 'Financial instruments of the poor: initial findings from the South African Financial Diaries study', Development Southern Africa 22 (5): 717-28.

Collins, D., J. Morduch, S. Rutherford and O. Ruthven (2009) Portfolios of the Poor: how the world's poor live on \$2 a day. Princeton NJ: Princeton University Press.

Cousins, B., T. Cousins, D. Hornby, R. Kingwill, L. Royston and W. Smit (2005) 'Will formalising property rights reduce poverty in South Africa's "second economy"?', Policy Brief 18, Programme for Land and Agrarian Studies, University of the Western Cape.

Davis, M. (2006) Planet of Slums. London: Verso.

de Soto, H. (2000) The Mystery of Capital. London: Bantam.

Devey, R., I. Valodia and C. Skinner (2006) 'Second best? trends and linkages in the informal economy in South Africa', DPRU Working Paper 06/102, Development Policy Research Unit, University of Cape Town.

Dugard, J. (2000) 'Taxi Wars in South Africa's Transition: the informalisation of violence and the economy'. Unpublished $\mathrm{PhD}$ thesis, University of Cambridge.

du Toit, A. and D. Neves (2007) 'Understanding self-employment at the margins of the South African economy: findings from a pilot study on qualitative approaches to self-employment'. Report by the Institute for Poverty, Land and Agrarian Studies (PLAAS) for the National Income Dynamics Study Steering Committee, Office of the Presidency, Cape Town.

Ferguson, J. (1992) 'The cultural topography of wealth: commodity paths and the structure of property in rural Lesotho', American Anthropologist 94 (1): 55-73. (1999) Expectations of Modernity: myths and meanings of urban life on the Zambian copperbelt. Berkeley CA: University of California Press.

Foxcroft, M., E. Wood, J. Kew, M. Herrington and M. Segal (2002) 'Global entrepreneurship monitor: South African executive report', Graduate School of Business, University of Cape Town. 
Fukuyama, F. (1995) 'Social capital and the global economy', Foreign Affairs 74 (5): 89-103.

Granovetter, M. (1985) 'Economic action and social structure: the problem of embeddedness', American Journal of Sociology 91 (3): 481-510.

(2005) 'The impact of social structure on economic outcomes', Journal of Economic Perspectives 19 (1): 33-50.

Granovetter, M. and R. Swedberg (2001) The Sociology of Economic Life. Boulder CO: Westview Press.

Guyer, J. I. (2004) Marginal Gains: monetary transactions in Atlantic Africa. Chicago IL: University of Chicago Press.

Hart, K. (1973) 'Informal income opportunities and urban employment in Ghana', Journal of Modern African Studies 11 (1): 61-89.

Humphrey, C. (2002) The Unmaking of Soviet life: everyday economies after socialism. Ithaca NY: Cornell University Press.

Kloosterman, R., J. van der Leun and J. Rath (1999) 'Mixed embeddedness: (in)formal economic activities and immigrant businesses in the Netherlands', International Journal of Urban and Regional Research 23 (2): 252-66.

KLS/CCT (2009) 'An audit of spaza shops in Khayelitsha, Cape Town'. Research report by Knowledge Cape Town: Link Services and the City of Cape Town.

Lund, F. and F. Skinner (2003) 'Integrating the informal economy in urban planning and governance: a case study of the process of policy development in Durban, South Africa', International Development Planning Review 26 (4): 431-56.

Maas, G. and M. Herrington (2006) 'Global Entrepreneurship Monitor: South African executive report 2006', Centre for Innovation and Entrepreneurship, University of Cape Town.

Mamdani, M. (1996) Citizen and Subject: contemporary Africa and the legacy of late colonialism. Princeton NJ: Princeton University Press.

Meagher, K. (2009) 'Culture, agency and power: theoretical reflections on informal economic networks and political processes', DIIS Working Paper 27, Danish Institute for International Studies, Copenhagen.

_ (2010) Identity Economics: social networks and the informal economy in Nigeria. Woodbridge: James Currey.

Neves, D., M. Samson, I. van Niekerk, S. Hlatshwayo and T. du Toit (2009) 'The use and effectiveness of social grants in South Africa'. Research report, FinMark Trust, Johannesburg.

Nyamnjoh, F. B. (2002) 'Domestication, agency and subjectivity in the Cameroonian Grassfields' in R. Werbner (ed.), Postcolonial Subjectivities in Africa. London: Zed Books.

Petersen, L. and A. Charman (2008) 'Making markets work for the poor-understanding the informal economy in Limpopo'. Report for the Limpopo Centre for Local Economic Development, commissioned by Sustainable Livelihood Consultants and Cardno Agrisystems, Cape Town.

Philip, K. (2009) 'Second economy strategy: addressing inequality and economic marginalisation: a strategy framework'. Strategy paper for Trade and Industrial Policy Strategies, Pretoria.

Polanyi, K. (1957) The Great Transformation. Boston MA: Beacon Press. 
Republic of South Africa (RSA) (2003) Government Gazette 461 (26), November. Cape Town: Government Printer, < http://www.info.gov.za/view/ DownloadFileAction?id=68002 > , accessed 3 June 2010.

Rogerson, C. M. (2007) "'Second economy” versus informal economy: a South African affair' Editorial, Geoforum 38 (6): 1053-7.

Roitman, J. (2003) 'Unsanctioned wealth, or the productivity of debt in northern Cameroon', Public Culture 15 (2): 211-37.

- (2005) Fiscal Disobedience: an anthropology of economic regulation in Central Africa. Princeton NJ: Princeton University Press.

Seekings, J. and N. Nattrass (2005) Class, Race and Inequality in South Africa. New Haven CT: Yale University Press.

Skinner, C. (2006) 'Securing livelihoods: a gendered analysis of support interventions available to street traders in the Durban metropolitian area', Research Report No. 34, Centre for Social and Development Studies (CSDS), University of KwaZulu-Natal.

Spiegel, A. (1996) 'Introduction: domestic fluidity in South Africa', Social Dynamics 22 (1): 5-6.

van Donge, K. J. (1992) 'Waluguru traders in Dar es Salaam: an analysis of the social construction of economic life', African Affairs 91 (363): 181-205.

von Broembsen, M. (2008) 'SMMEs, the informal sector and the "second economy", PLAAS Working Paper 10, Institute for Poverty, Land and Agrarian Studies, University of the Western Cape.

Western Cape Provincial Government (2005) 'Committee of inquiry into the underlying causes of instability and conflict in the minibus taxi industry in the Cape Town metropolitan area'. Report, Western Cape Provincial Government, Cape Town.

Wolpe, H. (1972) 'Capitalism and cheap labour power in South Africa: from segregation to apartheid', Economy and Society 1 (4): 425-56.

\section{ABSTRACT}

This article examines the interplay of agency, culture and context in order to consider the social embeddedness of money and trade at the margins of South Africa's economy. Focusing on small-scale, survivalist informal enterprise operators, it draws on socio-cultural analysis to explore the social dynamics involved in generating and managing wealth. After describing the informal sector in South Africa, the article elucidates the relationship between money and economic informality. First, diverse objectives, typically irreducible to the maximization of profit, animate those in the informal sector and challenge meta-narratives of a 'great transformation' towards socially disembedded and depersonalized economic relationships. Second, regimes of economic governance, both state-led and informal, shape the terrain on which informal economic activity occurs in complex and constitutive ways. Third, local idioms and practices of trading, managing money and negotiating social claims similarly configure economic activities. Fourth, and finally, encroaching and often inexorable processes of formalization differentially influence those in the informal sector. The analysis draws on these findings to recapitulate both the ubiquity and centrality of the sociality at the heart of economy, and to examine the particular forms they take in South Africa's informal economy. 


\section{RÉSUMÉ}

Cet article examine l'interaction de la culture, de l'action et du contexte pour étudier l'enchâssement social de l'argent et du commerce à la marge de l'économie sud-africaine. À travers le cas des entrepreneurs informels menant des activités de survie à petite échelle, il explore à partir d'une analyse socioculturelle la dynamique sociale qui intervient dans la génération et la gestion de patrimoine. Après avoir décrit le secteur informel en Afrique du Sud, l'article explique la relation entre l'argent et l'informalité économique. Premièrement, des objectifs divers, qui ne peuvent généralement pas se réduire à la maximisation du profit, animent les acteurs du secteur informel et remettent en question les métarécits d'une " grande transformation » vers des relations économiques socialement désenchâssées et personnalisées. Deuxièmement, des régimes de gouvernance économique (dirigés par l'État et informels) façonnent le terrain sur lequel survient l'activité économique informelle de manière complexe et constitutive multiple. Troisièmement, les idiomes locaux et les pratiques de commerce, de gestion d'argent et de négociation des revendications sociales configurent de la même façon les activités économiques. Enfin quatrièmement, des processus de formalisation envahissants et souvent inexorables influencent différentiellement ceux du secteur informel. L'analyse s'appuie sur ces conclusions pour récapituler à la fois l'ubiquité et la centralité de la socialité au cœur de l'économie, et pour examiner les formes particulières qu'elles prennent dans l'économie informelle en Afrique du Sud. 